Nowoczesne Systemy Zarządzania

Zeszyt 13 (2018), nr 2 (kwiecień-czerwiec)

ISSN 1896-9380, s. 153-154

Modern Management Systems

Volume 13 (2018), No. 2 (April-June)

ISSN 1896-9380, pp. 153-154

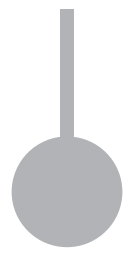

Instytut Organizacji i Zarządzania Wydział Cybernetyki

Wojskowa Akademia Techniczna w Warszawie

Institute of Organization and Management Faculty of Cybernetics Military University of Technology

\title{
Obchody 50-lecia Wydziału Cybernetyki Wojskowej Akademii Technicznej
}

\author{
Beata Czuba \\ Wojskowa Akademia Techniczna, \\ Wydział Cybernetyki
}

W czerwcu 2018 roku obchodziliśmy 50-lecie powstania Wydziału Cybernetyki WAT. Wydział został utworzony w 1968 roku, w odpowiedzi na ówczesne potrzeby Sił Zbrojnych. Kilkadziesiąt lat jego rozwoju w strukturze organizacyjnej WAT przyniosło wiele doniosłych osiągnięć i pozwoliło zbudować bardzo dobrą reputację jednostki w kraju i za granicą. Obecnie Wydział składa się z czterech instytutów: Instytutu Systemów Informatycznych, Instytutu Teleinformatyki i Automatyki, Instytutu Matematyki i Kryptologii oraz Instytutu Organizacji i Zarządzania. Jest największą jednostką organizacyjną Akademii i, jak na lidera przystało, kształci najliczniejszą grupę studentów (około 2 tys.) na studiach I, II i III stopnia oraz na studiach podyplomowych. Pracownicy naukowi Wydziału realizują także zajęcia z przedmiotów humanistycznych i społecznych na rzecz innych jednostek organizacyjnych uczelni. Oprócz działalności dydaktycznej, sukcesy pracowników Wydziału obejmują projekty oraz wynalazki, które zdobywają liczne nagrody w kraju i za granicą oraz znajdują zastosowanie w takich obszarach, jak informatyka, kryptologia, zarządzanie i bezpieczeństwo narodowe. Kilkudziesięcioletnia tradycja zobowiązuje, dlatego władze Wydziału oraz pracownicy dokładają starań, aby realizować zadania dydaktyczne i naukowe na wysokim poziomie merytorycznym. Oferta kierowana do studentów dostosowana jest do potrzeb zmieniającego się rynku. 
Obchody Święta Wydziału, które odbyły się 15 czerwca 2018 r., obejmowały wiele przedsięwzięć, $w$ tym konferencje, spotkania integracyjne, organizację wystawy, wydanie kilku publikacji. Dla uczestników były okazją do refleksji i przeżycia dumy oraz satysfakcji z tego, że są częścią zbiorowości o ciekawej historii i dużym kapitale społecznym. Podczas licznych wystąpień przypominano również o najważniejszych wartościach środowiska akademickiego. Święto było okazją do integracji pracowników, studentów i żołnierzy, którzy tworzą społeczność uczelni. Było także sposobnością uhonorowania tych wszystkich osób, które na co dzień, daleko od blasku fleszy, wypełniają rzetelnie swoje zawodowe i społeczne role, tworząc wartość dodaną tego złożonego sytemu ${ }^{1}$.

Beata Czuba

1 Opracowano na podstawie: https://wcy.wat.edu.pl/50lecie/obchody-jubileuszu [28.06.2018]; J. Rybiński, Zarys dziejów Wydziału Cybernetyki, [w:] W. Włodarkiewicz (red.), Wydział Cybernetyki Wojskowej Akademii Technicznej 1968-2008, Wyd. WAT 2008, s. 14-37. 